\title{
Structural development of vegetation on rehabilitated North Stradbroke Island: Above/belowground feedback may facilitate alternative ecological outcomes
}

\author{
Patrick Audet*, Amanda Gravina, Vanessa Glenn, Phill McKenna, Helen Vickers, Melina Gillespie and David Mulligan
}

\begin{abstract}
Introduction: This study depicts broad-scale revegetation patterns following sand mining on North Stradbroke Island, south-eastern Queensland, Australia.

Methods: Based on an ecological timeline spanning 4-20 years post-rehabilitation, the structure of these ecosystems ( $n=146$ ) was assessed by distinguishing between periods of 'older' (pre-1995) and 'younger' (post-1995) rehabilitation practices.
\end{abstract}

Results: The general rehabilitation outlook appeared promising, whereby an adequate forest composition and suitable levels of native biodiversity (consisting of mixed-eucalypt communities) were achieved across the majority of rehabilitated sites over a relatively short time. Still, older sites $(n=36)$ appeared to deviate relative to natural analogues as indicated by their lack of under-storey heath and simplified canopy composition now characterised by mono-dominant black sheoak (Allocasuarina littoralis) reaching up to $60 \%$ of the total tree density. These changes coincided with lower soil fertility parameters (e.g., total carbon, total nitrogen, and nutrient holding capacity) leading us to believe that altered growth conditions associated with the initial mining disturbance could have facilitated an opportunistic colonisation by this species. Once established, it is suspected that the black sheoak's above/belowground ecological behaviour (i.e., relating to its leaf-litter allelopathy and potential for soil-nitrogen fixation) further exacerbated its mono-dominant distribution by inhibiting the development of other native species.

Conclusions: Although rehabilitation techniques on-site have undergone refinements to improve site management, our findings support that putative changes in edaphic conditions in combination with the competitive characteristics of some plant species can facilitate conditions leading to alternative ecological outcomes among rehabilitated ecosystems. Based on these outcomes, future studies would benefit from in depth spatio-temporal analyses to verify these mechanisms at finer investigative scales.

Keywords: Eucalypts; Mono-dominance; Forest regeneration; Ecological restoration; Mineral sands; Mining

\footnotetext{
*Correspondence: p.audet@uq.edu.au

Centre for Mined Land Rehabilitation, Sustainable Minerals Institute,

The University of Queensland, Brisbane (St. Lucia), QLD 4072, Australia
} 


\section{Introduction}

Located off the south-eastern coast of Queensland, Australia, North Stradbroke Island is the World's second largest sand island $(\sim 27,500 \mathrm{ha})$ and the setting for wide-spread mining activity over much of the last halfcentury due to its richness in silica and heavy mineral ores (e.g., ilmenite, rutile, and zircon; Morley 1981). A requisite corollary of this activity has been the progressive rehabilitation of its disturbed lands ( 15\% area footprint) towards the post-mining land-use of self-sustaining native subtropical mixed-Eucalypt communities (EMRC 2006). Since 2005, environmental monitoring has been conducted to document the Island's annual development of rehabilitated forest blocks within the Amity, Bayside, Gordon and Ibis mining areas (Figure 1) by comparing the structure and composition of revegetated sites in relation to remnant ecosystems. Despite mostly satisfactory indications of post-rehabilitation development, preliminary field observations noted that black sheoak (Allocasuarina littoralis) - a regionally native tree species that was not highly prevalent among any of the reference communities-may be expressing unexpectedly 'weedy' behaviour among some of the rehabilitated sites (Gravina et al. 2011). Since similar behaviour by native woody species (e.g., Alloca- suarina and Acacia spp.) has been documented for rehabilitated coastal sites following mining elsewhere in Australia (Grant and Loneragan 1999, 2001; Norman and Grant 2005), these outcomes elicited fundamental questions as to the overall development of rehabilitated ecosystems on the Island and, more specifically, the potential mechanisms underlying the black sheoak's weedy proliferation.

The reconstruction of essential abiotic landform elements represents a critical first step in the rehabilitation of highly disturbed post-mining ecosystems (Doley et al. 2012). Thereafter, more subtle environmental drivers appear to be responsible for the convergence or divergence of rehabilitation outcomes relative to desired natural analogues (Grant 2006; Suding et al. 2004). These factors include the life-history strategies of the species used in revegetation and their potential for above- and belowground feedback relationships (Baer et al. 2002; Bonebrake et al. 2011; Kardol and Wardle 2010; Siddique et al. 2008). Together, such environmental drivers may represent key mechanisms underpinning species monodominance (or 'invasiveness') at the whole-ecosystem scale (Peh et al. 2011; Richardson et al. 2000; Rout and Callaway 2009; Wardle et al. 2004). Hence,
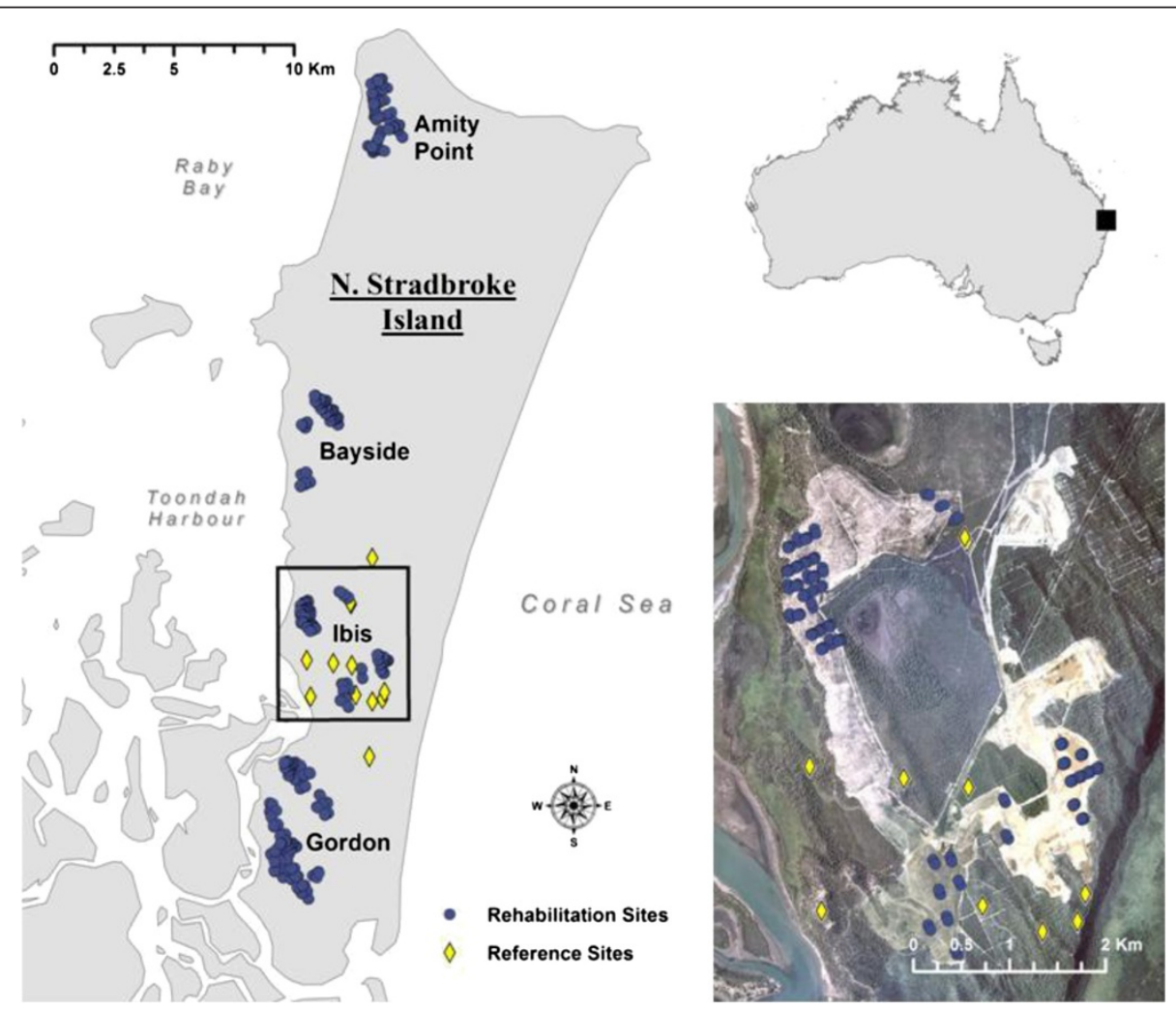

Figure 1 Distribution of long-term monitoring (LTM) plots on North Stradbroke Island. Aerial image (inset) was captured by Consolidated Rutile Ltd. in 2002. 
understanding of these relationships within the context of post-mining ecosystems would directly benefit rehabilitation planning and management.

To address these aspects, the monitoring record for North Stradbroke Island provides a relevant opportunity for determining the structural development of native vegetation among reconstructed ecosystems. Based on a depiction of land revegetation spanning a timeline of 4-20 years post-rehabilitation, this analysis seeks to describe broad-scale revegetation patterns (i.e., whether rehabilitated sites are mostly converging toward or diverging from natural analogues) and stipulate some of the factors potentially underlying this development. This depiction of ecological rehabilitation is unique insofar that, while the mining activity is entirely destructive toward the natural ecosystems, the removal of mineral ore from the underlying sand is not detrimental to the reconstruction of the essential landforms (Smith and Nichols 2011). In fact, the sand mining process does not produce or expose any toxic or biogeochemically unstable tailings that could otherwise significantly alter physicochemical growth conditions within the postdisturbance environment (Brooks 2000). Under these circumstances, targeting the veritable restoration of highly disturbed ecosystems following sand mining can be achieved within the range of feasible biological and socioeconomic outcomes-which is not equally applicable to many mine sites and alternative forms of mining (Doley and Audet 2013; Tibbett 2010). Since the purpose of land rehabilitation on North Stradbroke Island is the development of a sustainable ecosystem, ${ }^{\text {a }}$ such analyses will provide direct insight when formulating appropriate environmental management strategies toward the conservation of native species among transitional ecosystems.

\section{Bioregional description}

The Island (located at approximately $27.30^{\circ} \mathrm{E}$ and $153.25^{\circ} \mathrm{S}$ ) holds a total of 18 regional ecosystems and 7 distinct vegetation assemblages (Stephens and Sharp 2009), which can be grouped into three generic biological areas: (1) freshwater swamps, (2) beaches and fore-dunes, and (3) inland high dunes. Representing the main target of the mining activities, the high dunes cover $>50 \%$ of the island and are characterised by primary mature forests estimated to be up to 200 years old in some undisturbed locations (Rogers and Mokrzecki 1984). These open-forests and woodlands have an abundance of eucalypts and large Proteaceae as well as a generally sclerophyllous (or heathy) understorey (Clifford et al. 1979; Westman and Rogers 1977). The associated podzol soils (also known as podsols or spodosols) are strongly acidic and relatively infertile due to the illuviation of clay, organic matter and nutrient components (Isbell 2002; Thompson 1981, 1992).

\section{Mineral extraction and rehabilitation procedures}

According to Smith and Nichols (2011), the ongoing mineral extraction procedures (conducted by Consolidated Rutile Ltd., now Sibelco Australia Ltd.) have generally consisted of clearing all vegetation ahead of the mine path and stripping the topsoil layers (0$20 \mathrm{~cm}$ ) to enable mining of the underlying mineral sands. An artificial dredging pond was then created within the bare sand dunes to enable mining of 'wet' sands and extraction of mineral ore concentrates ( $\sim 1 \%$ of the total volume of sand). The rehabilitation process consisted of pumping the 'cleaned' residual

Table 1 Rehabilitation monitoring campaigns

\begin{tabular}{|c|c|c|c|c|c|}
\hline \multirow[t]{2}{*}{ Site } & \multicolumn{3}{|c|}{ Chronosequence } & \multirow{2}{*}{$\begin{array}{l}\text { Notable } \\
\text { Rehab. } \\
\text { Practice }\end{array}$} & \multirow{2}{*}{$\begin{array}{l}\text { No. Sample } \\
\text { Plots }\end{array}$} \\
\hline & $\begin{array}{l}\text { Rehab. } \\
\text { Year }\end{array}$ & $\begin{array}{c}\text { Monitoring } \\
\text { Year }\end{array}$ & $\begin{array}{c}\text { Time } \\
\text { Elapsed }\end{array}$ & & \\
\hline \multirow[t]{2}{*}{ Amity } & 1987 & 2007 & 20 & A & 2 \\
\hline & 1992 & 2010 & 18 & A & 12 \\
\hline \multirow[t]{4}{*}{ Bayside } & 1987 & 2007 & 20 & A & 2 \\
\hline & 1988 & 2008 & 20 & A & 5 \\
\hline & 1990 & 2005 & 15 & A & 4 \\
\hline & 1995 & 2005 & 10 & B & 5 \\
\hline \multirow[t]{8}{*}{ Gordon } & 1987 & 2007 & 20 & A & 3 \\
\hline & 1988 & 2008 & 20 & A & 6 \\
\hline & 1990 & 2010 & 20 & $A$ & 9 \\
\hline & 1994 & 2009 & 15 & A & 8 \\
\hline & 1998 & 2008 & 10 & B & 3 \\
\hline & 1999 & 2009 & 10 & B & 17 \\
\hline & 2000 & 2010 & 10 & $\mathrm{~B}$ & 4 \\
\hline & 1998 & 2005 & 7 & $B$ & 3 \\
\hline \multirow[t]{10}{*}{ Ibis } & 1998 & 2008 & 10 & B & 3 \\
\hline & 1998 & 2005 & 7 & B & 3 \\
\hline & 1999 & 2006 & 7 & $B$ & 5 \\
\hline & 2000 & 2007 & 7 & B & 9 \\
\hline & 2001 & 2008 & 7 & B & 8 \\
\hline & 2001 & 2005 & 4 & B & 8 \\
\hline & 2002 & 2006 & 4 & $B$ & 9 \\
\hline & 2003 & 2007 & 4 & $B$ & 7 \\
\hline & 2004 & 2008 & 4 & B & 9 \\
\hline & 2005 & 2009 & 4 & B & 2 \\
\hline Ref. & $n / a$ & 2010 & $\sim 200 \dagger$ & $n / a$ & 12 \\
\hline
\end{tabular}

Bold text refers to periods of bulk soil sampling.

$\mathrm{A}=$ Pre-1995: Direct seeding of black wattle (Acacia concurrens),

'early-flowering' black wattle (Ac. leicarpa) and black sheoak (Allocasuarina littoralis).

$B=$ Post-1995: black wattle discontinued; reduced seeding of black sheoak. +Undisturbed/remnant reference sites; broad estimates only (Rogers and Mokrzecki 1984). 
sands behind the dredging pond to reconstruct the dunes according to pre-disturbance topographic patterns (up to $150 \mathrm{~m}$ in height) and spreading the recovered topsoil over the landform. Topsoils were typically stockpiled up to 2 years and used as soon as possible in the rehabilitation process to preserve their native seed and soil-microbial components. The reconstructed landforms were simultaneously sprayed with a biodegradable emulsion to stabilise the surface matrix and seeded with a mixture of $\sim 30$ native trees, shrubs, and herbaceous species ( 25,000 seeds per hectare). Seeds were collected exclusively on the Island and selected to represent the essential species constituents from the reference communities ${ }^{\mathrm{b}}$ (EMRC Environmental Management Research Consultants 2006). Rehabilitated sites were fertilised at the initial emergence of seedlings and again 6-10 months thereafter using an NPK ratio deemed appropriate for the intended native species. At this time, the company's local nursery stocks were introduced to supplement the revegetation. Although subtle steps were enacted to encourage faunal recolonisation (e.g., nesting boxes, $\log$ piles), no further early-establishment procedures were implemented other than the attempted suppression of fire over the first 10-15 years post-rehabilitation and later the selective thinning of undesirable species.

Some of the rehabilitation techniques have undergone periodic refinements to improve site practices including the management of topsoil for a more careful preservation of biotic components and the adaptive modification of seeding mixes. Based on available documentation, these modifications were accounted for in our analyses by generally distinguishing between 'older' (pre-1995) and 'younger' (post-1995) rehabilitation practices (see the section 'Metrics and statistical analyses'). Notably, direct seeding of black wattle (Acacia concurrens) and 'early-flowering' black wattle (Ac. leiocarpa)-both of which form symbiotic associations with nitrogen-fixating Rhizobium spp.-was dramatically reduced and discontinued during 1992-1995 as a response to the establishment of mono-dominant stands of acacia among long-standing rehabilitated sites ${ }^{\mathrm{c}}$ (Rogers and Mokrzecki 1984). For similar reasons, the seeding rates of black sheoak (Allocasuarina littoralis, which forms symbiotic associations with nitrogen-fixating Frankia spp.) were gradually and pre-emptively reduced by an average $70 \%$ across all sites between 1987-1995 and 1996- present. $^{\mathrm{d}}$

\section{Methods}

\section{Ecological monitoring}

From 2005 to 2010, annual monitoring campaigns were conducted by the Centre for Mined Land Rehabilitation of The University of Queensland across representative rehabilitated landscapes located within the Amity, Bayside, Ibis, and Gordon mining areas (Figure 1) collectively spanning 4-20 years post-rehabilitation (Table 1). The survey also included four remnant/undisturbed locations nominated by the Rehabilitation Monitoring Program (EMRC 2006) to represent the predominant pre-mining vegetation communities (Tables 2 and 3). The reference communities were selected by the Environmental Authority (MIM800088202) to included a mixed distribution of (1) Eucalyptus racemosa woodland, (2) Corymbia intermedia, Allocasuarina torulosa, and Banksia serrata open forest, (3) E. pilularis woodland, and (4) E. planchoniana, B. aemula, and C. gummifera tall shrubland as described by the Queensland Herbarium (DERM, Gov't Queensland, Australia) since they are found across similar high dune sites throughout the Island.

Table 2 Predominant trees and shrubs found among reference and post-rehabilitation sites

\begin{tabular}{|c|c|c|c|}
\hline Order & Family & Taxon & $\begin{array}{l}\text { Common } \\
\text { Name }\end{array}$ \\
\hline \multirow[t]{2}{*}{ Cuppressaceae } & Callitroidae & Callitris columellaris & $\begin{array}{l}\text { White cypress- } \\
\text { pine }\end{array}$ \\
\hline & & Callitris rhomboidae & Oyster bay pine \\
\hline Fabales & Fabaceae & Acacia concurrenst & Black wattle \\
\hline \multirow[t]{2}{*}{ Fagales } & Casuarinaceae & $\begin{array}{l}\text { Allocasuarina } \\
\text { littoralisł }\end{array}$ & Black Sheoak \\
\hline & & $\begin{array}{l}\text { Allocasuarina } \\
\text { torulosa } \neq\end{array}$ & Forest Sheoak \\
\hline \multirow[t]{10}{*}{ Myrtales } & Myrtaceae & $\begin{array}{l}\text { Angophora } \\
\text { leiocarpa }\end{array}$ & Rusty gum \\
\hline & & $\begin{array}{l}\text { Corymbia } \\
\text { gummifera }\end{array}$ & Red bloodwood \\
\hline & & $\begin{array}{l}\text { Corymbia } \\
\text { intermedia }\end{array}$ & Pink bloodwood \\
\hline & & Eucalyptus pilularis & Blackbutt \\
\hline & & $\begin{array}{l}\text { Eucalyptus } \\
\text { planchoniana }\end{array}$ & $\begin{array}{l}\text { Bastard tallow- } \\
\text { wood }\end{array}$ \\
\hline & & $\begin{array}{l}\text { Eucalyptus } \\
\text { racemosa }\end{array}$ & Scribbly gum \\
\hline & & Eucalyptus resinifera & Red mahogany \\
\hline & & Eucalyptus tindaliae & $\begin{array}{l}\text { Tindale's } \\
\text { stringybark }\end{array}$ \\
\hline & & $\begin{array}{l}\text { Lophostemon } \\
\text { confertus }\end{array}$ & Brushbox \\
\hline & & $\begin{array}{l}\text { Melaleuca } \\
\text { quinquenervia }\end{array}$ & Paper bark \\
\hline \multirow[t]{2}{*}{ Proteales } & Proteaceae & Banksia aemula & Wallum Banksia \\
\hline & & Banksia serrata & Old man Banksia \\
\hline
\end{tabular}

Bold text refers to pre-dominant species found within the reference sites (Queensland Herbarium).

Note: A comprehensive list of species reported from high dune vegetation on North Stradbroke Island is available from Rogers and Mokrzecki (1984). tInteractions with $\mathrm{N}$-fixating Rhizobium spp.

fInteractions with $\mathrm{N}$-fixating Frankia spp. 
Table 3 Predominant ground-storey and mid-storey species found among reference and post-rehabilitation sites (including trees and shrubs)

\begin{tabular}{|c|c|c|c|}
\hline Order & Family & Taxon & Common Name \\
\hline \multirow[t]{2}{*}{ Apiales } & Apiaceae & Platysace ericoides & Heathy Platsace \\
\hline & Mackinlayaceae & Xanthosia pilosa & Wooly Xanthosia \\
\hline \multirow[t]{4}{*}{ Asparagales } & Iridaceae & Patersonia sericea & Silky Purple Flag \\
\hline & Laxmanniaceae & Laxmannia gracilis & Slender-Wire Lily \\
\hline & & Lomandra filiformis & Wattle Mat-Rush \\
\hline & & Lomandra longifolia & Spiny-Headed Mat-Rush \\
\hline \multirow[t]{2}{*}{ Asparagales } & Xanthorrhoeaceae & Dianella caerulea & Blue Flax-lily \\
\hline & & Xanthorrhoea johnsonii & Grass Tree \\
\hline \multirow[t]{2}{*}{ Caryophyllales/Dilleniales } & Dilleniaceae & Hibbertia acicularis & Prickly Guinea-Flower \\
\hline & & Hibbertia linearis & Guinea-Flower \\
\hline \multirow[t]{7}{*}{ Ericales } & Ericaceae & Brachyloma daphnoides & Daphne Heath \\
\hline & & Leucopogon ericoides & Pink Beard Heath \\
\hline & & Leucopogon leptospermoides & Bushy White Beard \\
\hline & & Leucopogon margarodes & Pearl Beard Heath \\
\hline & & Monotoca sp & None Recorded \\
\hline & & Styphelia viridis & Green Five Corners \\
\hline & & Woollsia pungens & Woollsia \\
\hline \multirow[t]{11}{*}{ Fabales } & Fabaceae & Acacia concurrens & Black Wattle \\
\hline & & Acacia sophorae & Coastal Wattle \\
\hline & & Acacia suaveolens & Sweet Wattle \\
\hline & & Acacia ulicifolia & Juniper Wattle \\
\hline & & Aotus ericoides & Common Aotus \\
\hline & & Aotus lanigera & Golden Candlestick \\
\hline & & Bossiaea ensata & Sword Bossiaea \\
\hline & & Bossiaea heterophylla & Variable Bossieae \\
\hline & & Daviesia ulicifolia & Gorse Bitter Pea \\
\hline & & Hardenbergia violacea & False Sarsaparilla \\
\hline & & Phyllota phylicoides & Yellow Pea-Bush \\
\hline \multirow[t]{2}{*}{ Fagales } & Casuarinaceae & Allocasuarina littoralis & Black Sheoak \\
\hline & & Allocasuarina torulosa & Forest sheoak \\
\hline Gentianales & Rubiaceae & Pomax umbellata & Pomax \\
\hline Laurales & Lauraceae & Cassytha pubescens & Devil's Twine \\
\hline Malvales & Thymelaeaceae & Pimelea linifolia & Queen-of-the-Bush \\
\hline \multirow[t]{13}{*}{ Myrtales } & Myrtaceae & Angophora leiocarpa & Rusty Gum \\
\hline & & Calytrix tetragona & Fringe Myrtle \\
\hline & & Corymbia gummifera & Red Bloodwood \\
\hline & & Corymbia intermedia & Pink Bloodwood \\
\hline & & Eucalyptus pilularis & Blackbutt \\
\hline & & Eucalyptus planchoniana & Bastard Tallow-wood \\
\hline & & Eucalyptus racemosa & Scribbly gum \\
\hline & & Eucalyptus resinifera & Red Mahogany \\
\hline & & Eucalyptus tindaliae & Tindale's Stringy Bark \\
\hline & & Homoranthus virgatus & None Recorded \\
\hline & & Leptospermum semibaccatum & None Recorded \\
\hline & & Leptospermum trinervium & Slender Tea-Tree \\
\hline & & Lophostemon confertus & Brush Box \\
\hline
\end{tabular}


Table 3 Predominant ground-storey and mid-storey species found among reference and post-rehabilitation sites (including trees and shrubs) (Continued)

\begin{tabular}{|c|c|c|c|}
\hline Pinales & Cupressaceae & Callitris sp & Cypress \\
\hline \multirow[t]{8}{*}{ Poales } & Cyperaceae & Caustis blakei & Koala Fern \\
\hline & & Caustis recurvata & Curly Sedge \\
\hline & & Lepidosperma laterale & Variable Saw Sedge \\
\hline & Poaceae & Aristida jerichoensis & Jericho Wiregrass \\
\hline & & Eragrostis spartinoides & Lovegrass \\
\hline & & Eriachne insularis & None Recorded \\
\hline & & Eriachne pallescens & None Recorded \\
\hline & & Imperata cylindrica & Blady Grass \\
\hline Poales & Restionaceae & Coleocarya gracilis & None Recorded \\
\hline \multirow[t]{9}{*}{ Proteales } & Proteaceae & Banksia aemula & Wallum Banksia \\
\hline & & Banksia oblongifolia & Fern-leaved Banksia \\
\hline & & Banksia serrata & Old-man Banksia \\
\hline & & Conospermum taxifolium & Devil's Rice \\
\hline & & Persoonia stradbrokensis & Snottygobbles/geebung \\
\hline & & Persoonia virgata & Snottygobbles/geebung \\
\hline & & Petrophile canescens & Conestick \\
\hline & & Schizachyrium fragile & Firegrass \\
\hline & & Strangea linearis & None Recorded \\
\hline Santalales & Santalaceae & Leptomeria acida & Sour Currant-Bush \\
\hline Sapindales & Rutaceae & Zieria laxiflora & Wallum Zieria \\
\hline
\end{tabular}

Permanent long-term botanic monitoring (LTM) plots were established across transects of selected post-mining sites $(n=146)$ and reference locations $(n=12)$. GPS and picket markers were established at each sampling site, and forest block aerial images and rehabilitation timelines were provided by the company. The LTM plots $(50 \times 20 \mathrm{~m})$ were divided into ten subplots $(10 \times 10 \mathrm{~m})$ with ten quadrats $(2 \times 2 \mathrm{~m})$ distributed at each end and on alternate sides of the primary plots (Appendix 1). Using a sighting tube and densitometer, the foliage projective cover [FPC (\%); canopy, >1.5 $\mathrm{m}$ in height; mid-storey, 0.5-1.5 m; or, ground-storey vegetation, $<0.5 \mathrm{~m}$ ] was assessed at $1 \mathrm{~m}$ intervals along the centre path of each $50 \mathrm{~m}$ LTM plot. The soil-surface projective cover [SPC (\%); litter, bare-soil, or basal vegetation] was also determined along this centre path. Since trees and sometimes large shrubs were used for determining the predominant regional vegetation assemblages, a grid system was devised to accurately record the abundance and distribution of species $(>2 \mathrm{~m}$ ) within each subplot $(\mathrm{n}=10$ per LTM). In the same manner, the abundance and percent projective cover of all ground-storey and mid-storey species (including emergent trees, small shrubs, herbaceous plants, and grasses) was recorded within each quadrat ( $\mathrm{n}=10$ per LTM). The taxonomic identity of all species was determined on-site and later verified using voucher specimens according to Stephens and Sharp (2009) and Bostock and Holland (2010). Semi-quantitative data were also collected at each site regarding notable geomorphological and ecological conditions (e.g., incidence of fire or drought, predominant litter components, additional species found outside of the sampling periphery).

\section{Soil chemical analyses}

Bulk soil samples $(5 \mathrm{~cm}$ deep $\times 10 \mathrm{~cm}$ wide soil cores) were collected from 73 rehabilitated plots and 8 reference plots, ${ }^{\mathrm{e}}$ and analysed according to Rayment and Higginson (1992). Total organic carbon (C Wt \% dry soil) was determined from $1.0 \mathrm{~g}$ ground and air-dried subsamples using the Heanes wet oxidation method, and total nitrogen (N Wt \% dry soil) was determined using the semi-micro Kjedahl steam distillation method. Olsen-extractable phosphorus [mg (P) $\mathrm{kg}^{-1}$ dry soil] was determined from 5 g soil samples suspended in $\mathrm{NaCO}_{3}$. The soil pH was measured from pure $\mathrm{H}_{2} \mathrm{O}$ suspensions using a 1:5 soil-to-solution ratio. Major and minor soil mineral concentrations [mg (+) $\mathrm{kg}^{-1}$ dry soil]_including $\mathrm{Al}, \mathrm{B}, \mathrm{Ca}, \mathrm{Cl}, \mathrm{Cu}, \mathrm{Fe}, \mathrm{K}$, $\mathrm{Mg}, \mathrm{Mn}, \mathrm{Na}, \mathrm{S}$, and $\mathrm{Zn}$-were determined from DTPA extracts and the cation exchange capacity [CEC mol $_{C}(+)$ $\mathrm{kg}^{-1}$ dry soil] measured from $\mathrm{NH}_{4} \mathrm{Cl}$ extracts. Standard reference materials from the Australasian Soil and Plant 
Analysis Council (ASPAC Inc., Carapook, VIC, Australia) were used to ensure the quality and accuracy of the chemical analyses.

\section{Metrics and statistical analyses}

The monitoring record for North Stradbroke Island was deemed suitable for generating a mosaic timeline of post-disturbance ecological development since all of the sites had a closely comparable spatial and geologic range (Walker et al. 2010), and standardised monitoring procedures were used throughout the period of data collection. Still, it is acknowledged that the ecological development of each rehabilitation block may be mutually exclusive (i.e., ongoing rehabilitation trajectories for certain sites may differ from others) due to their discontinuous rehabilitation histories. Data response variables included: \% FPC and \% SPC; abundance/density of mid-storey and ground-storey vegetation; abundance/density of large trees and shrubs (canopy); and selected soil properties. Still, a few minor data gaps were identified among these parameters resulting in some imbalances
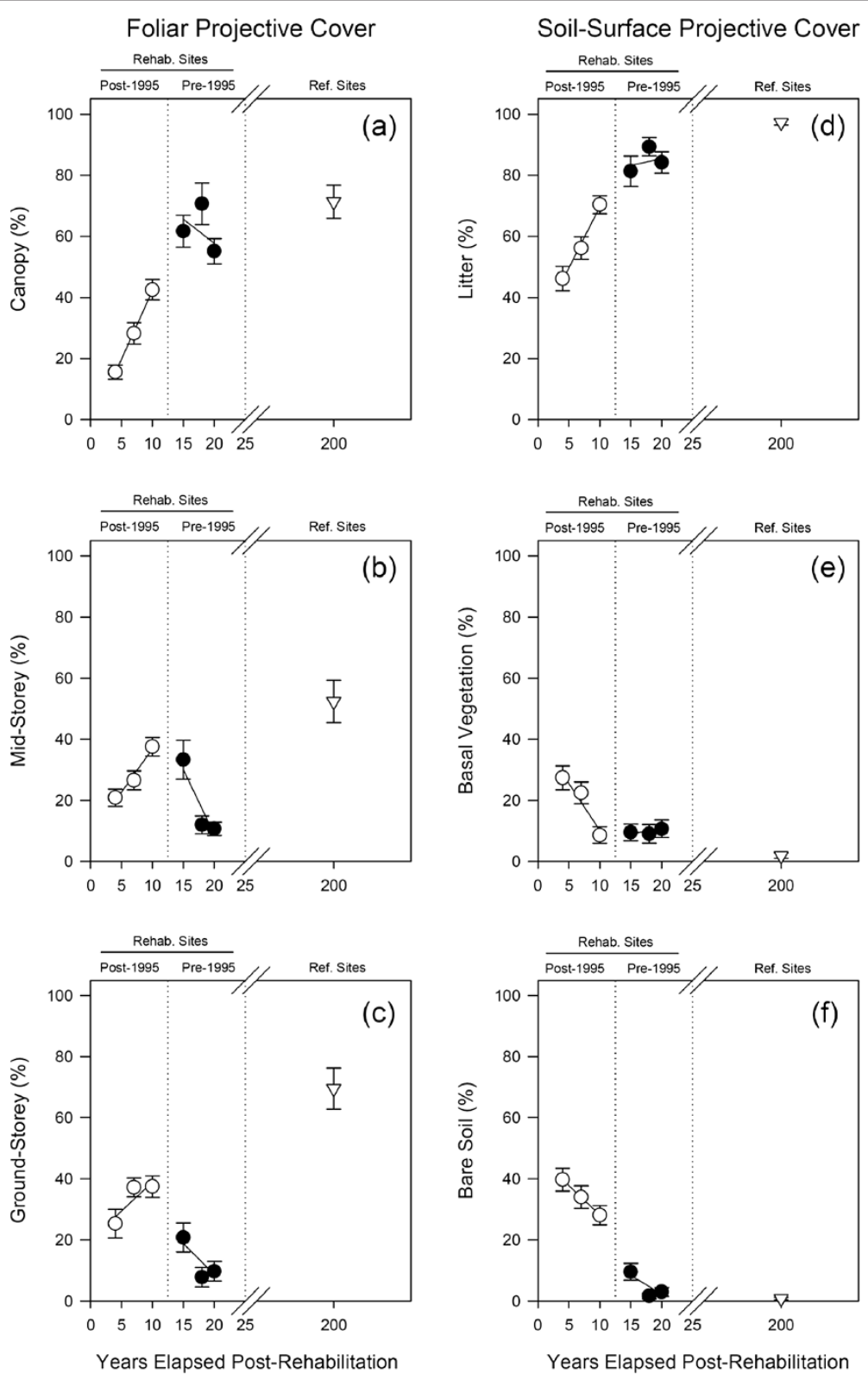

Figure 2 Foliar projective cover (FPC) and Soil Surface Cover (SPC). Percentage means and SE are shown for (a) canopy, (b) mid-storey, (c) ground-storey, (d) litter, (e) basal vegetation, and (f) bare soil. Lines of best-fit indicate potential trends and supporting summary statistics are provided in Appendix 3 (cf. Table 4). 
between the corresponding datasets. The site data were compiled by pooling subsamples within each LTM plot to avoid spatial duplication errors (e.g., $\mathrm{n}=$ 10 quadrats or subplots were equivalent to $n=1$ LTM). Also, certain data were converted and scaledup to provide more readily interpretable unit values (1 LTM $=0.1 \mathrm{ha}$ ). Species diversity indices (Shannon's $\mathrm{H}^{\prime}$ and Simpson's 1-D) were calculated from the pooled subsample data within each LTM plot. In this regard, $\mathrm{H}^{\prime}$ and 1-D estimates approaching 3.5 and 1, respectively, suggested high levels of species diversity (e.g., evenness and richness), whereas estimates approaching 1.5 and 0 suggested the contrary.

According to Zar (2010), linear models were fit to all of the data profiles to describe broad-scale spatio-temporal trends and identify general forest structure rehabilitation patterns. These analyses distinguished between periods of older (pre-1995) and younger (post-1995) rehabilitation practices which provided periodic treatment groupings across the timeline to account for general modifications to the rehabilitation protocols. Notably, among all of these analyses, a distinctive data trend associated with a single species (Allocasuarina littoralis, black sheoak) prompted separate analyses (as above) of its canopy density and proportional abundance. Log data transformations were applied across all analyses to meet the assumptions of the statistical tests. The residual fit-spread was used to verify normal data distribution and homogeneity of variance, and Cook's distances were used to verify the effects of potential outliers (data not shown). Non-parametric (ranked) analyses were applied when violations of the test assumptions were inevitable (e.g., due to data response variables prone to zeros in the dataset) which, ultimately, provided the same statistical outcomes as the parametric tests. Linear equations $[f(x)]$, coefficients of determination $\left(r^{2}\right)$, degrees of freedom $(d f)$, and $p$-value estimates were determined using Statistica 9.1 (StatSoft Inc., Tulsa, OK, USA). Data trends were inferred from inspection of the data trajectories toward values of the reference communities.

\section{Results}

Foliar projective cover (FPC; Figure $2 \mathrm{a}-\mathrm{c}$ ) and soilsurface projective cover (SPC; Figure $2 \mathrm{~d}-\mathrm{f}$ ) were determined for the post-mining rehabilitated and undisturbed/remnant reference sites and analysed by distinguishing between periods of older (pre-1995) vs. younger (post-1995) rehabilitation practices. Typical of early forest regeneration, the FPC and SPC generally indicated trajectories on course to achieve similar levels to the adjacent reference sites. For example, cover levels up to $75 \%$ in the canopy and up to $40 \%$ in the mid- and ground-storey were found. This development resulted in the rapid increase in litter $(>95 \%)$ and the subsequent decrease in emergent basal vegetation and bare surface exposure (both from $20 \%$ to $<5 \%$ ). However, upon closer analysis of the older sites $(n=36)$, their mid-storey (Figure $2 \mathrm{~b})$ and ground-storey covers (Figure 2c) were unexpectedly lower (from $40 \%$ to $10 \%$ ) than the reference sites. This tendency was also found for estimates of ground-storey and mid-storey species diversity and density (Figure 3a-b). Species richness and evenness were not substantially different across the entire timeline (Shannon's $\mathrm{H}^{\prime}$ ranging from 2 to 2.5; Simpson's 1 -D ranging from 0.7 to 0.9 ). Yet, species density was dramatically lower (ranging from 180 to 50 individuals) among rehabilitated sites, especially for the older sites.

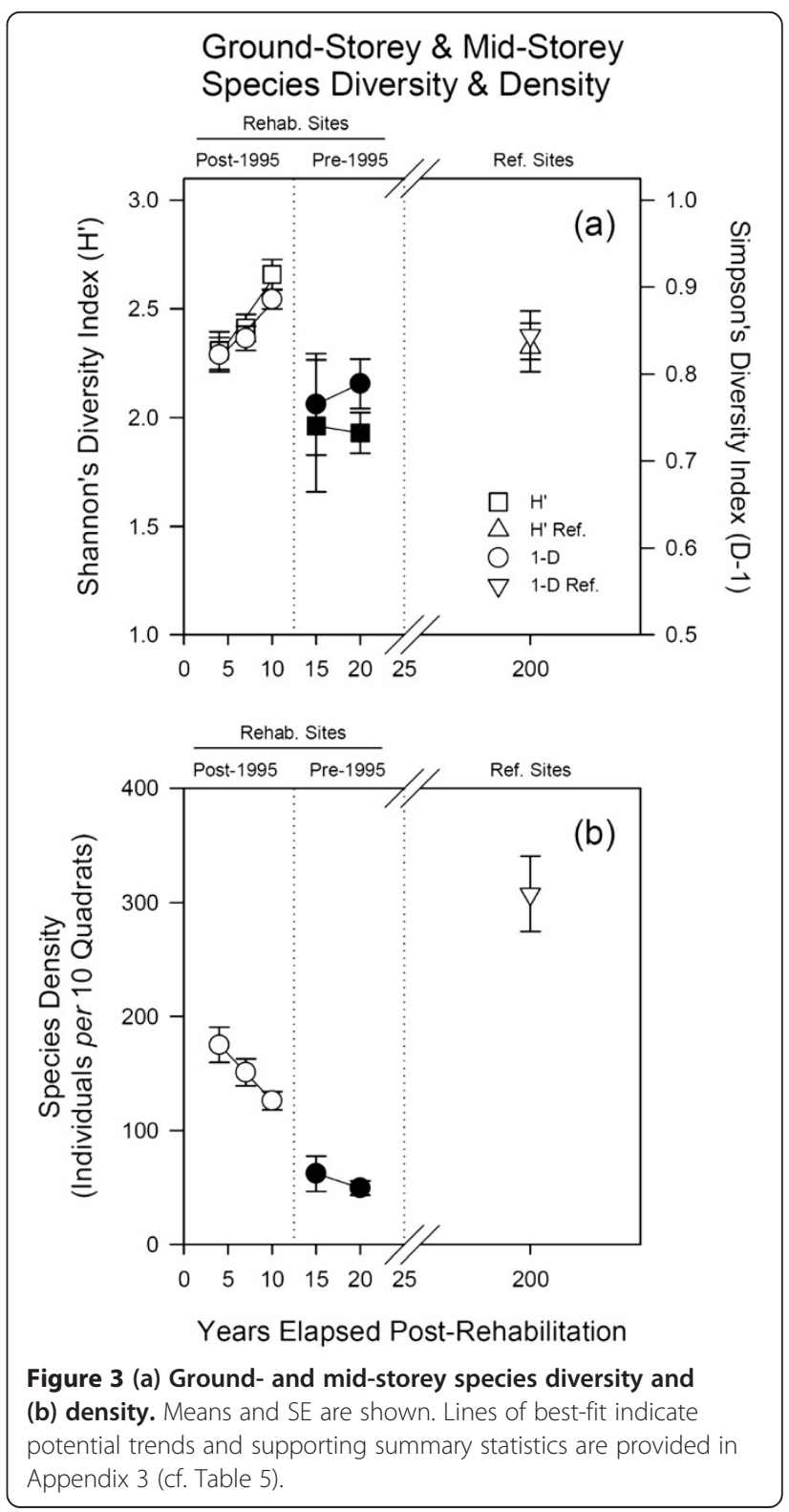


The density and diversity of large trees $(>2 \mathrm{~m})$ was determined (Figure $4 \mathrm{a}-\mathrm{d}$ ) and again indicated trajectories which were typical of early forest regeneration. The total canopy density of all rehabilitated sites generally increased (from 500 to 1,300 stems per ha at breast height) across the timeline and was similar to the reference sites. The richness and evenness of species was highest among younger sites $\left(\mathrm{H}^{\prime}\right.$ ranging from 1.6 to 2 ; 1-D $\left.\sim 0.8\right)$, whereas older sites indicated lower values ( $\mathrm{H}^{\prime}$ from 1.5 to 1.2 ; $1-\mathrm{D}$ from 0.7 to 0.55 ) which approached similar levels to the reference sites and suggested that species composition had reached a climax. Overall, all of the anticipated native reference species were identified and fairly well represented (based on presence/absence) among the majority of rehabilitated sites (data not shown). However, of the 17 most prominent species found among both the reference and rehabilitation sites, a divergent data trend was identified stemming from a single species (Allocasuarina littoralis, black sheoak), which prompted separate analyses of its canopy density (Figure 4c) and proportional abundance (Figure 4d). While mostly absent from the reference communities, the black sheoak showed significantly higher canopy density (from 200 to 600 stems per ha) and reached up to $60 \%$ of the total species abundance among the older sites. In this regard, our on-site field observations noted that, where this species was abundant, the ground-storey was dominated by its dense needle-like litter-mat (often up to $3 \mathrm{~cm}$ thick).

Lastly, edaphic parameters (Figure 5a-f) were determined for most of the LTM plots. Key differences included lower total carbon $(0.5-1.0 \% \mathrm{C})$ and total nitrogen $(0.03-0.06 \% \mathrm{~N})$ for the rehabilitated vs. reference sites $(1.5 \% \mathrm{C} ; 0.08 \% \mathrm{~N})$, and lower (from 35:1 to 20:1) carbon-to-nitrogen ratios for all rehabilitated sites. The $\mathrm{pH}$ of rehabilitated soils also decreased (from 5.1 to 4.8 ), but values were not as low as the reference sites (4.5). The soil's nutrient holding capacity was considerably lower among rehabilitated sites (CEC from 0.8 to $0.6 \mathrm{~mol}_{\mathrm{c}} \mathrm{kg}^{-1}$ dry soil) than the reference sites $\left(1.25 \mathrm{~mol}_{\mathrm{c}} \mathrm{kg}^{-1}\right.$ dry soil). The latter trend (i.e., lower soil fertility in rehabilitated vs. reference sites) was also found regarding the concentrations of major and minor soil nutrients (e.g., $\mathrm{Al}$, $\mathrm{B}, \mathrm{Ca}, \mathrm{Cl}, \mathrm{Cu}, \mathrm{Fe}, \mathrm{K}, \mathrm{Mg}, \mathrm{Mn}, \mathrm{Na}, \mathrm{S}, \mathrm{Zn}$ ), albeit having no distinct or remarkable trends of their own (data not shown). Based on soil classification criteria
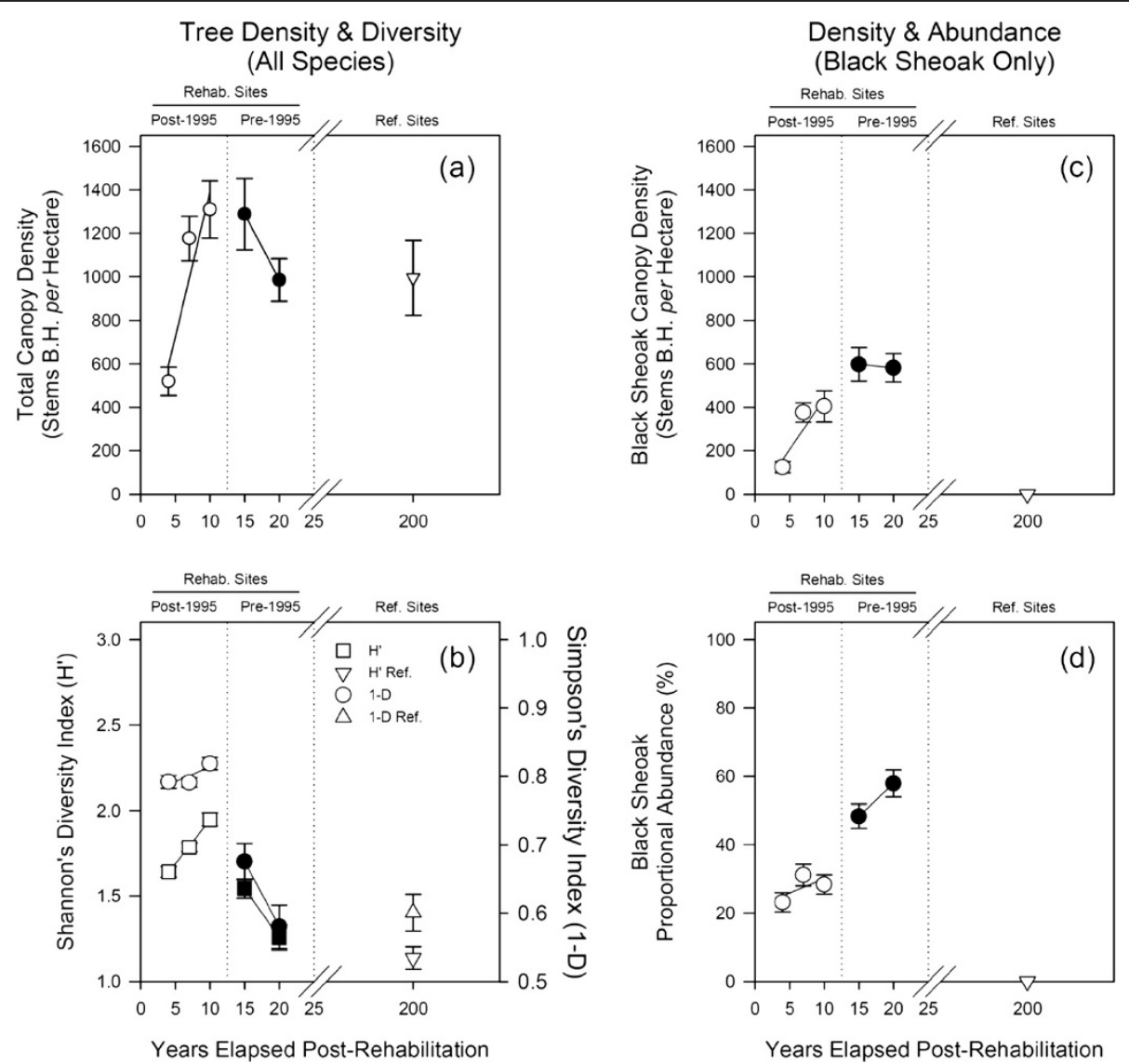

Figure 4 (a) Density and (b) diversity for all canopy species. (c) Density and (d) proportional abundance of black sheoak. Lines of bestfit indicate potential trends and supporting summary statistics are provided in Appendix 3 (cf. Table 6). 


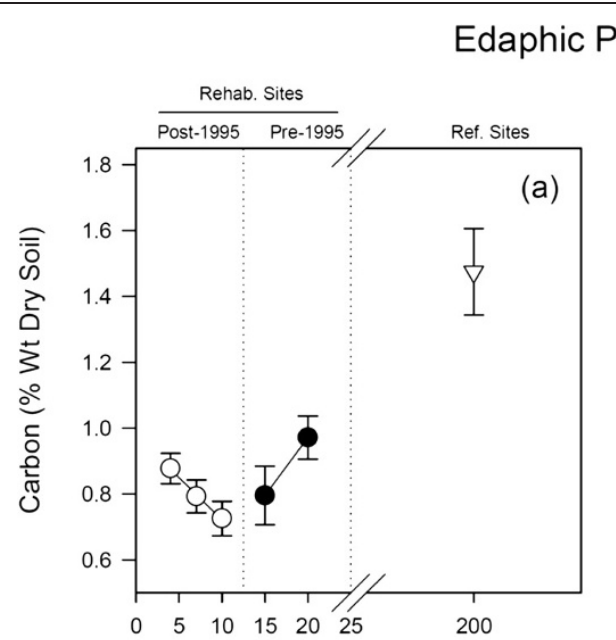

\section{Parameters}
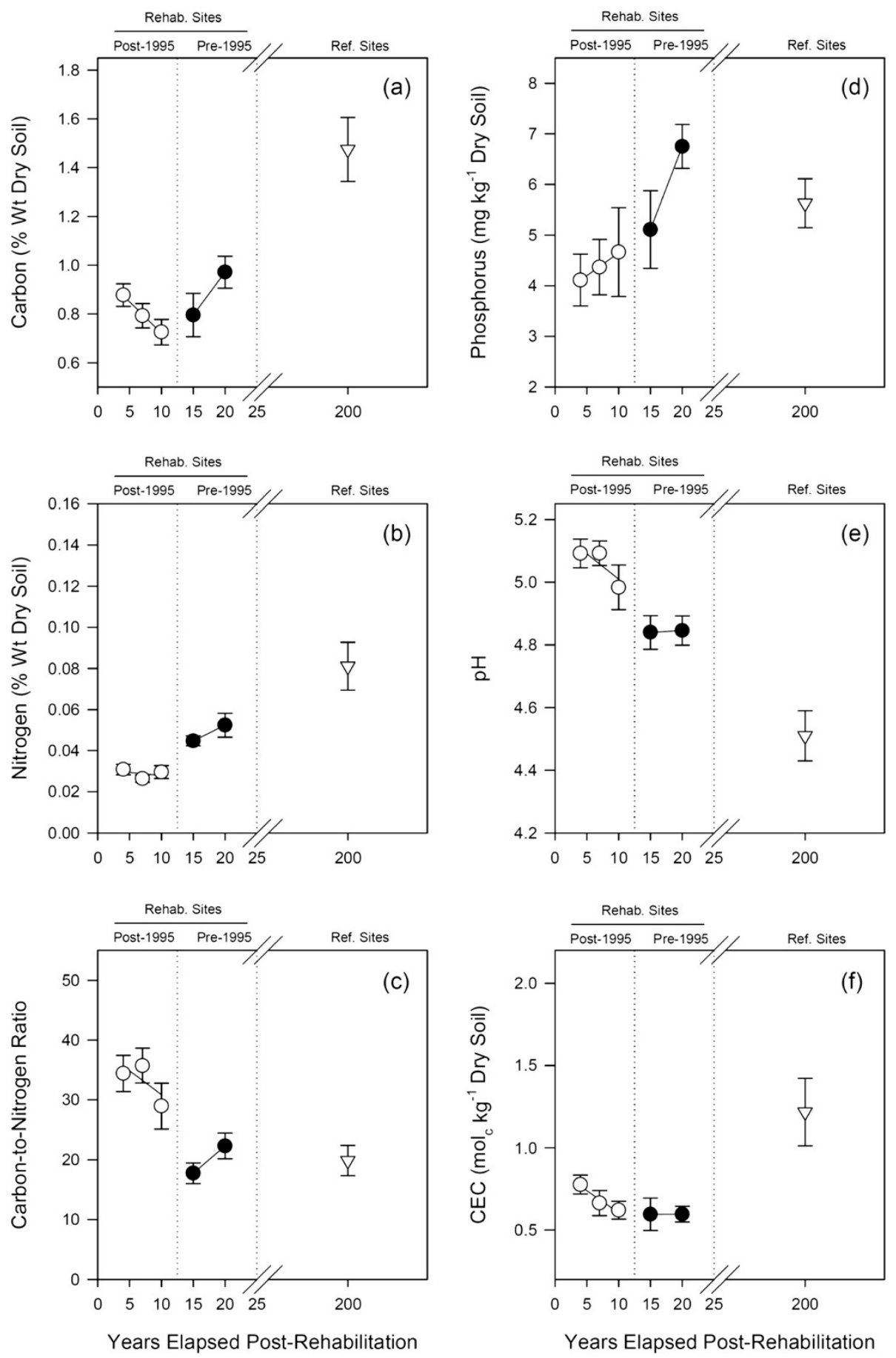

Figure 5 General soil nutritional parameters. Means and SE for (a) total carbon, (b) total nitrogen, (c) carbon-to-nitrogen ration, (d) phosphorus, (e) soil pH, and (f) soil cation exchange capacity (CEC) are shown. Lines of best-fit indicate potential trends and supporting summary statistics are provided in Appendix 3 (cf. Table 7).

(e.g., Isbell 2002), these broad edaphic parameters suggest that the rehabilitated sites were nutrientpoor early-podzol soils in contrast to the relatively more fertile late-podzol reference sites (Appendix 2).
Data trends (above) were inferred from inspection of the data trajectories toward values of the reference communities. All of the supporting summary statistics (regarding the fit and significance of the linear trends 
in relation to treatment groupings) are provided in (Appendix 3).

\section{Discussion}

Overall, the broad-scale rehabilitation outlook for North Stradbroke Island appears promising, whereby an adequate forest composition consisting of desired native vegetation has been achieved across most sites over a relatively short time. With certain key exceptions (described further below), this wide-spread establishment of stable and mostly self-sustaining ecosystems should represent a successful example of land rehabilitation given the size and scale of the anthropogenic disturbance impact and the inherent challenges of reconstructing coastal landscapes. Still, as anticipated from previous field observations, the trajectories of older sites appear to have diverged from their intended natural analogues. Despite having appropriate canopy development, these sites showed lower structural cover in the mid- and under-storeys corresponding with dramatically lower species density within these forest zones. This would suggest that they developed an open-forest canopy structure but not the desired sclerophyllous under-storey, unlike the development of the younger rehabilitated sites and long-standing undisturbed reference sites (Clifford et al. 1979; Specht and Specht 1989; Westman and Rogers 1977). Furthermore, analyses of canopy composition confirmed the emergence of black sheoak (Allocasuarina littoralis) as a predominant species among many older sites-reaching up to $60 \%$ of the total tree species density-instead of the desired mixed eucalypt-dominated communities. Since these structural and compositional differences aligned closely with the different periods of land rehabilitation practices, an intriguing aspect pertains to how conditions within the older rehabilitated environments could have enabled the native black sheoak to colonise and then so fundamentally alter the form of the rehabilitated ecosystems. Given that changes in the vegetation composition generally coincided with differences among various growth parameters, we consider that a combination of abiotic factors (e.g., alterations to the post-disturbance soil conditions) and biotic factors (e.g., 'pioneer' life-history strategies) could have facilitated this unintended rehabilitation outcome (Baer et al. 2002; Bonebrake et al. 2011; Siddique et al. 2008). Even though site practices have improved over time and younger sites appear to express mostly compliant ecological development within the range of acceptable outcomes, understanding of these phenomena among older sites could provide necessary insight into the management of potentially divergent ecosystems. Based on these outcomes, future studies would benefit from in-depth spatio-temporal analyses to verify these mechanisms at finer investigative scales.

\section{Altered growth conditions enable opportunistic colonisation}

An inevitable consequence of the mineral sands mining process is the disturbance of the soil's matrix structure due to the pre-mining stripping of the topsoil layers (Smith and Nichols 2011). While this strategy is often used to reintegrate native seed and soil-microbial components into the rehabilitated ecosystems (Rokich et al. 2000), the practice of stripping and stockpiling topsoil renders the reconstructed soils relatively more susceptible to weathering and loss of biotic viability (Abdul-Kareem and McRae 1984; Koch et al. 1996). This should account for the generally lower soil fertility parameters found among the rehabilitated vs. reference sites (e.g., total carbon content, total nitrogen content, soil-nutrient content and holding capacity). Admittedly, topsoil rehabilitation practices among 'older' sites were not as thoroughly documented as for younger sites; still, we suspect that more detrimental soil changes were likely to have occurred among the older sites due to putatively longer periods of stockpiling. Another consequence of the mining disturbance is the reversion of the soil's podzolization status (referring to the proportional depths of the A1, A2, and B horizons) compared to the more distinctly stratified soils found among the undisturbed sites due to the industrial processing of the sandy sub-soils (Appendix 2). These aspects are significant since the natural patterns of vegetation establishment on the dunes of eastern Australia have been closely correlated with the soil's nutrient bioavailability and associated podzolization status (Thompson 1981, 1992). In these coastal environments, the intended mixed-Eucalypt communities typically populate high dune environments having intermediate- to late-stage podzol soils (Westman 1975; Westman and Rogers 1977). By contrast, pioneer and/or facilitator species such as black sheoak often populate the adjacent fore-dunes, which have early-stage podzol soils (Lunt 1998b). Recalling that this latter species was directly seeded as part of the rehabilitation strategy (albeit at different seeding intensities depending on the period of rehabilitation), it is suspected that the loss of soil fertility and its reversion to an early podzol status would have facilitated initial growth conditions conducive to the species' opportunistic colonisation due to its general 'ruderal' adaptations to nutrient-poor conditions (Crowley 1984; Diem et al. 2000). Conversely, such postdisturbance soil conditions could have been 
disadvantageous for the desired and relatively slowergrowing mixed-Eucalypts that are typically only sparsely distributed among the fore-dunes (Westman 1975). For these reasons, we suspect that altered edaphic conditions associated with the management of post-disturbance soils along with the seeding of pioneer species likely contributed the primary first steps leading to the divergence of older rehabilitated sites away from the intended natural analogues-unlike younger sites where soil conditions are believed to have been more carefully managed.

\section{Mono-dominance as a result of leaf litter allelopathy}

Further to factors associated with soil disturbance, we also consider that (once established) the black sheoak's above- and belowground feedback behaviour could have facilitated its mono-dominant distribution. Characteristic of all Casuarinaceae, the foliage of Allocasuarina spp. consists of waxy needle-shaped leaves that produce a dense litter-mat (Crowley 1984). Although true allelopathic compounds have yet to be identified, the thick and slowly decomposing litter layer is considered to suppress seed germination by shading and then inhibit seedling establishment. Consequently, Casuarinaceae-dominated ecosystems tend to form a closed canopy structure with an open under-storey (Lunt 1998a, 1998b). Likewise, a key onsite observation in our study indicated that, where the black sheoak was most abundant, the soil surface was predominately blanketed by its 'needles', which ultimately coincided with the substantial decrease in mid-storey and ground-storey species density. Hence, this soil-canopy feedback could be responsible for disrupting the development of under-storey heath while maintaining the pre-dominant black sheoak canopy composition (Facelli and Pickett 1991) which is critical for post-mining sites where the pedogenesis of the reconstructed soils has often been reverted to a 'younger' soil status (described above). Accordingly, Peh et al. (2011) have suggested that the lack of exogenous disturbance combined with soil nutrient deficiency and the persistence of soil-surface cover-as reported here-can result in species mono-dominance and/or arrested development. Given that black sheoak are believed to live for about 30 years (probably due to its fire response) within the natural succession of coastal ecosystems (Crowley 1984), a general concern for the older rehabilitated environments is that this feedback cycle could perpetuate an ecological regime shift away from the intended Eucalypt-dominated forests (Lindenmayer et al. 2011). Since some of the younger sites currently demonstrate an increasing proportional abundance of black sheoak (e.g., up to $35 \%$ in some locations), time will tell whether these sites (which are otherwise on course to achieve similar compositional and structural levels as the reference sites) could develop toward a similar state of arrested development without any future management intervention. Still, this scenario is unlikely given the company's current awareness of divergent vs. convergent forest blocks, its pre-emptive modification of seeding rates, and active mitigation of 'weedy' species proliferation as part of contemporary rehabilitation practices.

On a related topic, Lunt (1998a) predicted that Casuarinaceae-dominated litter should have implications for any potential fire regime (or lack thereof), particularly due to its composition as a compact ground fuel that may not burn under mild fire conditions. Whereas regular fire disturbances as part of natural succession enable coastal eucalypt forests to sustain their openwoodland structure and ensure the regeneration of under-storey species, the lack of any such fire regime could lead to arrested development (Bradstock et al. 2012; Pyke et al. 2010). While the suppression of fire is a beneficial part of the rehabilitation process to prevent scorching of juvenile species, it likely inadvertently influenced the accumulation of Black Sheoak litter among certain rehabilitated forest blocks and further exacerbated its detrimental effects on the development of mid-storey and ground-storey vegetation therein. Since black sheoak is part of the native coastal landscape, the implementation of selective thinning and carefully managed fire regimes would help to reduce the incidence of mono-dominant stands in favour of the desired native mixed-eucalypts, as suggested by Chaffey and Grant (2000), Smith et al. (2001, 2004), and later Shackleford et al. (2013) for the management of undesirable species among similar Australian forest ecosystems.

\section{Mono-dominance as a result of $\mathrm{N}$-fixation}

A final (yet more tenuous) mechanism potentially contributing to the emergence of black sheoak monodominance relates to the species' symbiotic (i.e., actinorhizal) enrichment of soil N. Although the rehabilitated sites generally had significantly lower soil fertility than the reference sites, soil $\mathrm{N}$ enrichment appeared (circumstantially) to correlate with the black sheoak's increasing proportional abundance. This outcome reflects upon the rehabilitated sites achieving an increasingly stable and self-sustaining ecological status. However, it is suspected that the enrichment of soil-N pools (especially in the topsoil rather than in lower substrata) could alter the proportional distribution of soil nutrients to the benefit of species better adapted for nutrient scavenging (Diem et al. 2000). While further experimental investigation would be needed to verify these facets on North Stradbroke Island, the predominance of $\mathrm{N}$-fixing species 
(including Acacia spp. and Allocasuarina spp.) among rehabilitated ecosystems can bring about cumulative changes to edaphic conditions (Lamb 2011; Siddique et al. 2008). This mechanism, among others, could account for initial reports of 'weedy' behaviour by these species on other rehabilitated mine sites (Grant and Loneragan 1999, 2001). Given that $\mathrm{N}$ is often a limiting factor affecting primary productivity among temperate ecosystems, N-fixation has been proposed as a plantdriven feedback mechanism affecting the composition of vegetation assemblages (Knops et al. 2002; Laungani and Knops 2009). Within a wider ecological context, Rout and Callaway (2009) have identified this mechanism as potentially underlining an invasive plant paradox whereby above- and belowground biotic relationships (particularly those involving $\mathrm{N}$-cycling) can facilitate plant invasionsor, in this case, mono-dominance-and all the while increase soil nutrient stocks. Hence, this plant-soil-N feedback mechanism could represent a key ecological driver affecting the development of vegetation assemblages among rehabilitated subtropical ecosystems, as well.

\section{Conclusions}

Based on our findings, the majority of rehabilitated sites on North Stradbroke Island appear to have achieved a functional and self-sustaining forest structure consisting of the desired native mixed-eucalypt species as part of the prescribed rehabilitation strategy. Still, by focussing our attention on sites and site conditions expressing divergent ecological development, we hypothesized factors putatively underlying the coincidental lack of under-storey heath and 'weedy' proliferation of black sheoak among 'older' rehabilitated sites, thereby providing a potential template for future analysis at finer investigative resolutions. These factors included the following:

1) The apparent loss of soil fertility and biotic viability due to the nature of the disturbance.

2) The behaviour of plants as pioneer and/or facilitator species within these environments.

3) The ability of plants to form above/belowground feedback relationships that directly impact biodiversity patterns.

While it is recognised that periodic refinements of rehabilitation practices have reduced the incidence of mono-dominance among more recent rehabilitated forest blocks, we still recommend that considerations be made regarding the broader ecological context for species recolonisation when planning post-disturbance ecosystems to account for and even avoid potentially unintended rehabilitation outcomes. Otherwise, provisions should be made to implement adaptive interventions (e.g., selective thinning and/or burning) to ensure the form and function of the desired ecosystems within the range of natural ecological regimes.

\section{Natural or novel?}

Veritable ecological restoration following any form of disturbance is dependent on whether the critical physical resources assembled during the rehabilitation process adequately resemble the pre-disturbance conditions. In this regard, Hobbs et al. $(2006,2013)$ rightfully suggested that the degree to which disturbances cause ir/reversible changes to ecosystem structure and function should predetermine the likelihood of near/natural restoration vs. the development of hybrid or novel ecosystems - thereby putting into question whether restoration (sensu strictu) is always achievable after all (Choi 2007; Seastedt et al. 2008). In our study, subtle and perhaps even benign ecological factors (listed above) appear to underlie the divergent and/or alternative development of certain rehabilitated sites despite the careful implementation and refinement of rehabilitation practices. These outcomes point to the inherent complexity and implicit challenges of reconstructing highly disturbed, post-mining ecosystems as well as the acknowledgment that, when possible, contemporary rehabilitation approaches should continually be replaced by something better. Fortunately, we suspect that sites on North Stradbroke Island deemed to be divergent and characterised by mono-dominant stands of black sheoak are in a state of arrested development likely resulting in hybrid ecological assembly, structure, and function. Even though these sites are both safe and stable within the natural landscape, careful monitoring and active management over time should contribute to the emulation of pre-disturbance ecological conditions.

\section{Endnotes}

${ }^{\text {a }}$ Projected for inclusion in the expansion of the Naree Budjon Djara - My Mother Earth National Park.

${ }^{\mathrm{b}}$ The initial seeding mix also contained infertile sorghum to provide a short-lived vegetation cover which facilitated early surface stabilisation and organic matter production.

${ }^{\mathrm{c}}$ These sites (referring to those subjected to pre-1987 rehabilitation procedures) were not considered in the present analysis.

${ }^{\mathrm{d}}$ Mean site seeding rates of black sheoak were reduced from $31.4 \pm 1.8 \mathrm{~g}$ seed $\mathrm{ha}^{-1}$ during 1987-1995 to $9.5 \pm$ $1.0 \mathrm{~g}$ seed $\mathrm{ha}^{-1}$ during 1996-present; from 2001present, seeding rates were further reduced to $3.1 \pm 1.0$ $\mathrm{g}$ seed $\mathrm{ha}^{-1}$ (Environmental Office, Sibelco, Australia Ltd., personal communications).

${ }^{\text {e}}$ Selective sampling rates were due to the requirements of the compliance monitoring program, but data are still representative of the entire timeline (cf. Table 1 ). 


\section{Appendix 1}

Figure 6

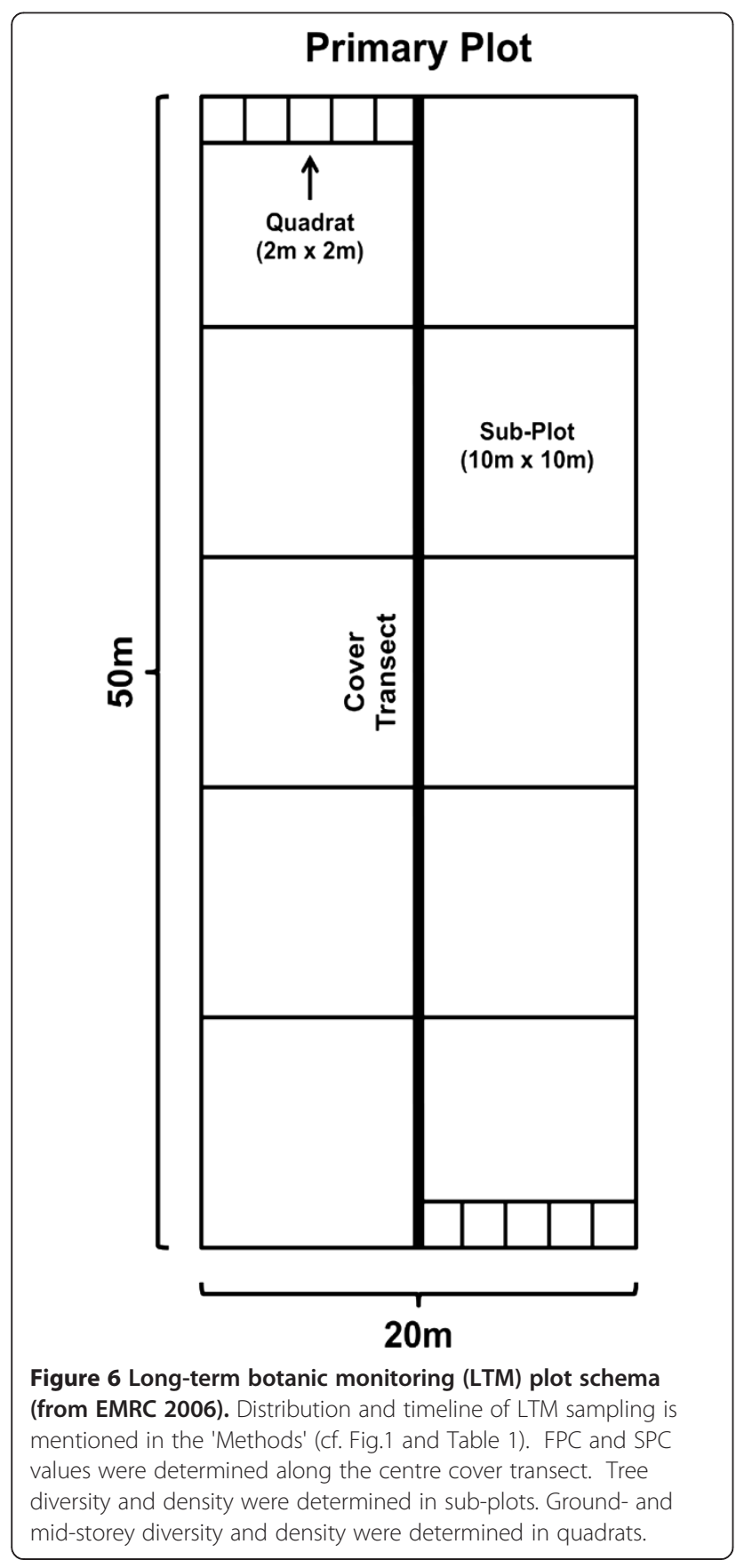

\section{Appendix 2}

Figure 7

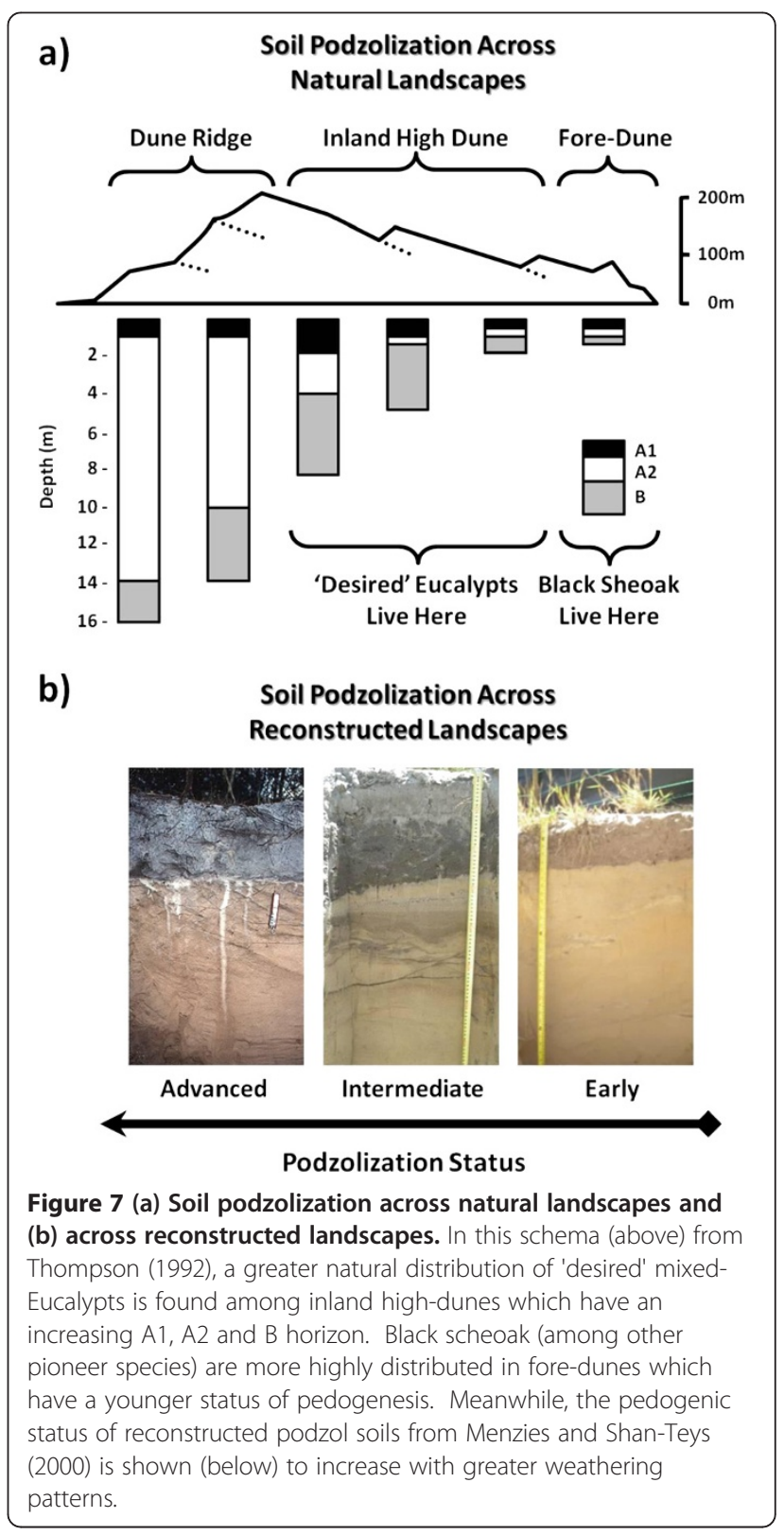




\section{Appendix 3}

Tables 4, 5, 6 and 7

Table 4 Regression summaries for the foliar projective cover (FPC, \%) and soil-surface projective cover (SPC, \%)

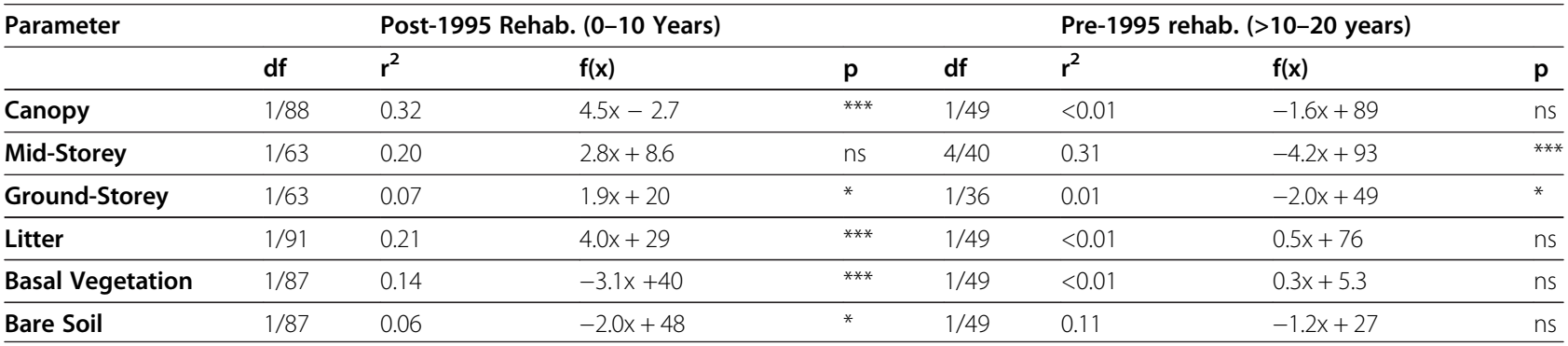

ns - non-significant, ${ }^{*} p<0.05,{ }^{* * *} p<0.01$.

Table 5 Regression summaries for the diversity and density of ground-storey and mid-storey species

\begin{tabular}{|c|c|c|c|c|c|c|c|c|}
\hline \multirow[t]{2}{*}{ Parameter } & \multicolumn{4}{|c|}{ Post-1995 Rehab. (0-10 Years) } & \multicolumn{4}{|c|}{ Pre-1995 Rehab. (>10-20 Years) } \\
\hline & df & $r^{2}$ & $f(x)$ & $p$ & $d f$ & $r^{2}$ & $f(x)$ & $p$ \\
\hline Shannon's H' & $1 / 88$ & 0.11 & $0.06 x+2.1$ & *** & $1 / 21$ & $<0.01$ & $-0.006 x+2.1$ & ns \\
\hline Simpson's 1-D & $1 / 88$ & 0.08 & $0.01 x+0.8$ & *** & $1 / 21$ & $<0.01$ & $0.005 x+0.7$ & ns \\
\hline Species Density & $1 / 88$ & 0.08 & $-8.1 x+208$ & *** & $1 / 21$ & 0.04 & $-2.5 x+99$ & ns \\
\hline
\end{tabular}

ns - non-significant, ${ }^{* * *} p<0.01$.

Table 6 Regression summaries for the density, diversity, and proportional abundance of canopy species

\begin{tabular}{|c|c|c|c|c|c|c|c|c|}
\hline \multirow[t]{2}{*}{ Parameter } & \multicolumn{4}{|c|}{ Post-1995 Rehab. (0-10 Years) } & \multicolumn{4}{|c|}{ Pre-1995 Rehab. (>10-20 Years) } \\
\hline & df & $r^{2}$ & $f(x)$ & $p$ & df & $r^{2}$ & $f(x)$ & $p$ \\
\hline Total Density (All Species) & $1 / 92$ & 0.25 & $132 x+61$ & $* * *$ & $1 / 37$ & 0.07 & $-60 x+2193$ & ns \\
\hline Specific Density (Black Sheoak) & $1 / 92$ & 0.14 & $46 x-28$ & $* * *$ & $1 / 37$ & $<0.01$ & $-3.1 x+644$ & ns \\
\hline Shannon's Index & $1 / 71$ & 0.23 & $0.05 x+1.5$ & $* * *$ & $1 / 23$ & 0.20 & $-0.06 x+2.4$ & * \\
\hline Simpson's Index & $1 / 71$ & 0.02 & $0.003 x+0.8$ & ns & $1 / 23$ & 0.12 & $-0.02 x+0.9$ & $\overline{\mathrm{ns}}$ \\
\hline Proportional Abundance (Black Sheoak) & $1 / 92$ & 0.04 & $1.4 x+15$ & * & $1 / 37$ & 0.06 & $1.9 x+20$ & ns \\
\hline
\end{tabular}

ns - non-significant, ${ }^{*} p<0.05,{ }^{* * *} p<0.01$.

Table 7 Regression summaries for the edaphic conditions

\begin{tabular}{|c|c|c|c|c|c|c|c|c|}
\hline \multirow[t]{2}{*}{ Parameter } & \multicolumn{4}{|c|}{ Post-1995 Rehab. (0-10 Years) } & \multicolumn{4}{|c|}{ Pre-1995 Rehab. (>10-20 Years) } \\
\hline & df & $r^{2}$ & $f(x)$ & $p$ & df & $r^{2}$ & $f(x)$ & $\bar{p}$ \\
\hline Carbon & $1 / 62$ & 0.07 & $-0.03 x+1.0$ & ns & $1 / 32$ & 0.06 & $0.04 x+0.3$ & * \\
\hline Nitrogen & $1 / 58$ & 0.01 & $-0.001 x+0.03$ & ns & $1 / 32$ & 0.02 & $0.001 x+0.02$ & ns \\
\hline Carbon/Nitrogen & $1 / 58$ & 0.05 & $-0.8 x+39$ & ns & $1 / 32$ & 0.04 & $0.9 x+4.1$ & ns \\
\hline Phosphorus & $1 / 58$ & 0.01 & $0.09 x+3.7$ & ns & $1 / 20$ & 0.12 & $0.3 x+0.2$ & $\overline{\mathrm{ns}}$ \\
\hline $\mathrm{pH}$ & $1 / 62$ & 0.03 & $-0.02 x+5.2$ & ns & $1 / 32$ & 0.22 & $0.001 x+4.8$ & $\mathrm{~ns}$ \\
\hline CEC & $1 / 62$ & 0.04 & $-0.03 x+0.9$ & ns & $1 / 32$ & $<0.01$ & $0.001 x+0.6$ & $\mathrm{~ns}$ \\
\hline
\end{tabular}

ns - non-significant, ${ }^{*} p<0.05$. 


\section{Abbreviations}

LTM: Long-term monitoring; FPC: Foliage projective cover; SPC: Surface projective cover.

\section{Competing interests}

The authors declare that they have no competing interests with regard to any of the reported findings.

\section{Authors' contributions}

PA gathered, analysed, and interpreted the data and was primarily responsible for drafting the manuscript. AG, VG, PM, HV, and MG gathered the data and contributed field-level observations. DM provided editorial commentary. All authors read and approved the final manuscript.

\section{Acknowledgements}

The authors recognise the traditional landowners of North Stradbroke Island (Minjerribah), the Quandamooka People. We also thank the special-issue guest editor (Michael Perring) and three anonymous reviewers for their insightful commentary, as well as past/present staff at North Stradbroke Island's operations of Sibelco Australia Ltd. for their active cooperation within the project. This study was made possible through funding from Sibelco (previously Consolidated Rutile Ltd.), the Sustainable Minerals Institute, and the Centre for Mined Land Rehabilitation. Further independent financial support was awarded to PA from the University of Queensland as well as the Natural Sciences and Engineering Research Council (NSERC-CRSNG) of Canada.

Received: 18 March 2013 Accepted: 6 June 2013

Published: 8 July 2013

\section{References}

Abdul-Kareem AW, McRae SG (1984) The effects on topsoil of long-term storage in stockpiles. Plant Soil 76:357-363

Baer SG, Kitchen DJ, Blair JM, Rice CW (2002) Changes in ecosystem structure and function along a chronosequence of restored grasslands. Ecol Appl 12:1688-1701

Bonebrake TC, Navratil RR, Boggs CL, Fendorf S, Field CB, Erlich PR (2011) Native and non-native community assembly through edaphic manipulation: Implications for habitat creation and restoration. Restor Ecol 19:709-716

Bostock PD, Holland AE (ed) (2010) Census of the Queensland Flora 2010. Queensland Herbarium, Department of Environment and Resource Management, Brisbane

Bradstock RA, Gill AM, Williams RJ (ed) (2012) Flammable Australia: fire regimes, biodiversity and ecosystems in a changing world. CSIRO Publishing, Collingwood, VIC, Australia

Brooks D (2000) Reclamation of lands disturbed by mining of heavy minerals. In: Barnhisel Rl, Darmody RG, Daniels WL (ed) Reclamation of drastically disturbed lands, Agronomy Monograph 41. American Society of Agronomy, Crop Science Society of America, Soil Science Society of America, Madison, WI, USA, pp 725-754

Chaffey CJ, Grant CD (2000) Fire management implications of fuel loads and vegetation structure in rehabilitated sand mines near Newcastle, Australia. Forest Ecol Manag 129:269-278

Choi YD (2007) Restoration ecology to the future: a call for new paradigm. Restor Ecol 15:351-353

Clifford HT, Speight RL, Speight MM (1979) The vegetation of North Stradbroke Island, Queensland. University of Queensland Press, Brisbane, QLD, Australia

Crowley GM (1984) Ecology of Allocasuarina littoralis (Salisb.) L. Johnson and A. torulosa (Ait) L. Johnson in North Queensland. PhD. Dissertation. James Cook University, Townsville, QLD, Australia

Diem HG, Duhoux E, Zaid H, Arahou M (2000) Cluster roots in Casuarinaceae: Role and relationship to soil nutrient factors. Ann Bot 85:929-936

Doley D, Audet P (2013) Adopting novel ecosystems as suitable rehabilitation alternatives for former mine sites. Ecol Process 2:22

Doley D, Audet P, Mulligan D (2012) Examining the Australian context for postmined land rehabilitation: Reconciling a paradigm for the development of natural and novel ecosystems among post-disturbance landscapes. Agric Ecosys Environ 163:85-93

EMRC (Environmental Management Research Consultants) (2006) Rehabilitation monitoring system: Recommended monitoring program to assess the development of rehabilitated ecosystems following Consolidated Rutile Ltd. mineral sand mining at North Stradbroke Island, Queensland. Technical report. EMRC, Brisbane, QLD, Australia Technical report, May 2006
Facelli JM, Pickett STA (1991) Plant litter: Its dynamics and effects on plant community structure. Bot Rev 57:1-31

Grant CD (2006) State-and-transition successional model for bauxite mining rehabilitation in the jarrah forest of Western Australia. Restor Ecol 14:28-37

Grant CD, Loneragan WA (1999) The effects of burning on the understorey composition of rehabilitated bauxite mines in Western Australia: community changes and vegetation succession. Forest Ecol Manag 145:255-279

Grant CD, Loneragan WA (2001) The effects of burning on the understorey composition of 11-13 year-old rehabilitated bauxite mines in Western Australia-vegetation characteristics. Plant Ecol 145:291-305

Gravina A, McKenna P, Glenn V (2011) Evaluating the success of mineral sand mine rehabilitation on North Stradbroke Island, Queensland: Comparisons with reference Eucalypt communities. Proc R Soc QLD 117:419-436

Hobbs RJ, Arico S, Aronson J, Baron JS, Bridgewater P, Cramer VA, Epstein PR, Ewel JJ, Klink CA, Lugo AE, Norton D, Ojima D, Richardson DM, Sanderson EW, Valladares F, Vila M, Zamora R, Zobel M (2006) Novel ecosystems: theoretical and management aspects of the new ecological world order. Global Ecol Biogeogr 15:1-7

Hobbs RJ, Higgs ES, Hall CM (ed) (2013) Novel Ecosystems: Intervening in the New Ecological World Order. John Wiley \& Sons, Chichester

Isbell R (2002) The Australian soil classification. CSIRO, Collingwood, VIC, Australia

Kardol P, Wardle DA (2010) How understanding aboveground-belowground linkages can assist restoration ecology. Trends Ecol Evol 25:670-679

Knops JMH, Bradley KL, Wedin DA (2002) Mechanisms of plant species impacts on ecosystem nitrogen cycling. Ecol Lett 5:454-466

Koch JM, Ward SC, Grant CD, Ainsworth GL (1996) Effects of bauxite mine restoration operations on topsoil seed reserves in the jarrah forest of western Australia. Restor Ecol 4:368-376

Lamb D (2011) Re-greening the bare hills: Tropical forest restoration in the Asia-Pacific region. Springer, Berlin

Laungani R, Knops JMH (2009) Species-driven changes in nitrogen cycling can provide a mechanism for plant invasions. Proc Nat Acad Sci USA 106:12400-12405

Lindenmayer DB, Hobbs RJ, Likens GE, Krebs CJ, Banks SC (2011) Newly discovered landscape traps produce regime shifts in wet forests. Proc Nat Acad Sci USA 108:15887-15891

Lunt ID (1998a) Allocasuarina (Casuarinaceae) invasion of an unburnt coastal woodland at Ocean Grove, Victoria: Structural change 1971 to 1996. Austr J Bot 46:649-656

Lunt ID (1998b) Two hundred years of land use and vegetation change in a remnant coastal woodland in southern Australia. Austr J Bot 46:629-647

Menzies N, Shan-Teys M (2000) Soil profile development in rehabilitation areas. In: Harwood M, Corbett M (ed) Ecosystem development following heavy mineral sand mining on North Stradbroke Island. Assessment of rehabilitation and the development of indicators of rehabilitation success. Internal report to CRL, September 2000. Centre for Mined Land Rehabilitation, The University of Queensland, Brisbane, QLD, Australia

Morley IW (1981) Black sands: a history of the mineral sand mining industry in eastern Australia. University of Queensland Press, Brisbane, QLD, Australia

Norman MA, Grant CD (2005) Weed potential of wood jarrah forest species previously used in bauxite mine rehabilitation. Research Report No. 34. Alcoa World Alumina Australia, Applecross, WA, Australia

Peh KSH, Lewis SL, Lloyd J (2011) Mechanisms of mono-dominance in diverse tropical tree-dominated systems. J Ecol 99:891-898

Pyke DA, Brooks ML, d'Antonio CM (2010) Fire as a restoration tool: a decision framework for predicting the control or enhancement of plants using fire. Restor Ecol 18:274-284

Rayment GE, Higginson FR (1992) Australian laboratory handbook of soil and water chemical methods. Inkata, Melbourne, VIC, Australia

Richardson DM, Allsopp N, d'Antonio CM, Milton SJ, Rejmánek M (2000) Plant invasions: The role of mutualisms. Biol Rev 75:63-93

Rogers RW, Mokrzecki S (1984) Succession following sand mining of high dunes, North Stradbroke Island. In: Coleman RJ, Covacevich J, Davie P (ed) Focus on Stradbroke. New information on North Stradbroke Island and surrounding areas 1974 to 1984, Boolarong, Brisbane, QLD, Australia, pp 260-266

Rokich DP, Dixon KW, Sivasithamparam K, Meney KA (2000) Topsoil handling and storage effects on woodland restoration in Western Australia. Restor Ecol 8:196-208

Rout ME, Callaway RM (2009) An invasive plant paradox. Science 324:734-735

Seastedt TR, Hobbs RJ, Suding KN (2008) Management of novel ecosystems: are novel approaches required? Front Ecol Environ 6:547-553 
Shackelford N, Renton M, Perring MP, Hobbs RJ (2013) Modelling disturbancebased control of native invasive species and its implications for management. Ecol Appl. in press

Siddique I, Engel VE, Parrotta JA, Lamb D, Nardoto GB, Ometto JPHB, Martinelli LA, Schmidt S (2008) Dominance of legume trees alters nutrient relations in mixed species forest restoration plantings within seven years. Biogeochemistry 88:89-101

Smith P, Nichols O (2011) Development and assessment of rehabilitation criteria for high dune mineral sands mining on North Stradbroke Island. Proc R Soc QLD 117:347-364

Smith MA, Loneragan WA, Grant CD, Koch JM (2001) Effect of fire on the topsoil seed banks of rehabilitated bauxite mine sites in the jarrah forest of Western Australia. Ecol Manage Restor 1:50-60

Smith MA, Grant CD, Loneragan WA, Koch JM (2004) Fire management implications of fuel loads and vegetation structure in jarrah forest restoration on bauxite mines in Western Australia. Forest Ecol Manage 187:247-266

Specht RL, Specht A (1989) Species richness of overstorey strata in Australian plant communities - the influence of overstorey growth rates. Austr J Bot 37:321-326

Stephens KM, Sharp D (2009) The flora of North Stradbroke Island. Queensland Herbarium, Environmental Protection Agency, Brisbane, QLD, Australia

Suding KN, Gross KL, Houseman GR (2004) Alternative states and positive feedbacks in restoration ecology. Trends Ecol Evol 19:46-53

Thompson CH (1981) Podzol chronosequence on coastal dunes of eastern Australia. Nature 291:59-61

Thompson CH (1992) Genesis of podzols on coastal dunes in southern Queensland: I. Field relationships and profile morphology. Austr J Soil Res 30:593-613

Tibbett M (2010) Large-scale mine site restoration of Australian eucalypt forests after bauxite mining: soil management and ecosystem development. In: Batty LC, Hallberg KB, Kevin B, Jarvis A (ed) Ecology of industrial pollution. Cambridge University Press, UK, pp 309-326

Walker LR, Wardle DA, Bardgett RD, Clarkson BD (2010) The use of chronosequences in studies of ecological succession and soil development. J Ecol 98:725-736

Wardle DA, Bardgett RD, Klironomos JN, Van der Putten WH, Wall DH (2004) Ecological linkages between aboveground and belowground biota. Science 304:1629-1633

Westman WE (1975) Pattern and diversity in swamp and dune vegetation, North Stradbroke Island. Austr J Bot 23:339-354

Westman WE, Rogers RW (1977) Biomass and structure of a subtropical Eucalypt forest, North Stradbroke Island. Austr J Bot 25:171-191

Zar JH (2010) Biostatistical Analysis, 5th edition. Prentice Hall, Upper-Saddle River, NJ, USA

doi:10.1186/2192-1709-2-20

Cite this article as: Audet et al: Structural development of vegetation on rehabilitated North Stradbroke Island:

Above/belowground feedback may facilitate alternative ecological outcomes. Ecological Processes 2013 2:20.

\section{Submit your manuscript to a SpringerOpen ${ }^{\circ}$ journal and benefit from:}

- Convenient online submission

- Rigorous peer review

- Immediate publication on acceptance

- Open access: articles freely available online

- High visibility within the field

- Retaining the copyright to your article

Submit your next manuscript at $\gg$ springeropen.com 